\title{
Adhesives based on formaldehyde - environmental problems
}

\author{
Maria ŁebKowska, Monika ZaŁęska-Radziwile, Agnieszka Tabernacka* \\ Division of Biology, Faculty of Building Services, Hydro and Environmental Engineering, \\ Warsaw University of Technology, Warszawa, Poland
}

\begin{abstract}
Adhesives are substances that increase the surface adhesion of bonded items. Unfortunately, they also emit volatile organic compounds (VOCs) which negatively impact upon human and animal health. VOCs have carcinogenic and mutagenic properties and can cause migraines, irritation to the eyes, nasal passages, mouth, and lungs, and respiratory problems. Wastewater from adhesive production is characterized by high levels of pollutants and contains high concentrations of compounds including formaldehyde that are toxic to water biocenoses. Moreover, its purification causes many problems and requires the application of specific methods. This review presents data concerning the toxicity and ecotoxicity of selected adhesives components. VOC emission rates from adhesives and wooden construction elements with adhesives are also discussed and assessed. Current knowledge on the treatment methods for wastewater containing adhesive components is reviewed. Finally, the treatment and disposal methods for solid wooden waste containing adhesives are also analyzed and discussed.
\end{abstract}

Key words: adhesives, formaldehyde, wastewater treatment

\section{Introduction}

Adhesives are substances that increase the surface adhesion of bonded items. The main component of adhesives is a natural or synthetic polymer in colloid state dispersed in a solvent or in a mixture, together with hardeners, plasticizers and other compounds modifying the composition.

There should be strong cohesion between the particles of an adhesive. The highest conjugation energy is found in ionic or atomic bonds. Substances built from elements connected in this way are resistant and durable, and are difficult to melt or dissolve. The liquid form of adhesives is produced by using solvents or liquid dispersion agents.

The main goal of using adhesives is to form a thin layer of congealed adhesive with good mechanical characteristics between bonded items. Adhesives can be categorized by the method of adhesion into: solvent-based adhesives; polymer dispersion adhesives (resins); and mixed adhesives. Synthetic adhesives include resorcinol adhesives based on resorcinol resin, phenol resin and formaldehyde resin, amine adhesives based on melamine resin, urea-formaldehyde (UF) resins, polyurethane adhesives, polyvinyl adhesives, phthalic adhesives, polyacrylic adhesives, and silicone-based and epoxide adhesives. Adhesives are widely used in the production of wooden (structural) construction elements, such as girders, rafters, columns and trusses, and in the production of plywood, particleboards, fiberboards, wood veneers, joiner boards, wood flooring and furniture. Currently, the most commonly used adhesives are those based on urea-formaldehyde resin, polyurethane, epoxide, polyester and polyvinyl acetate (McDermott et al., 2007).

Adhesives are a source of volatile organic compounds (VOCs) which negatively impact upon human and animal health as a result of inhalation and skin contact. They may cause allergic reactions and have carcinogenic and mutagenic properties. It has been found that VOCs have strong neurotoxic effects and can cause allergies, migraines, irritation to the eyes, nasal passages, mouth, and lungs, and respiratory problems. Small doses of toluene, hexane and methyl ethyl ketone have

\footnotetext{
* Corresponding author: Division of Biology, Faculty of Building Services, Hydro and Environmental Engineering, Warsaw University of Technology, Nowowiejska 20, 00-653 Warszawa, Poland; e-mail: agnieszka.tabernacka@is.pw.edu.pl
} 
been shown to damage membranes of human neurons in as few as five days (McDermott et al., 2007). Wastewaters from adhesive resin production are characterized by high levels of pollutants and contain high concentrations of compounds that are toxic to water biocenoses.

In this study, the toxicity and ecotoxicity of selected wood adhesive components are presented, including the emission of formaldehyde (FA) and VOCs, from wood elements of interior design to indoor air. The methods of treating wastewater from formaldehyde resin production and wood waste are also described. It should be noted that there are few data available concerning the impact of adhesives on organisms and ecosystems, or the ecological consequences of storing and landfilling used wood products.

\section{Toxicity and ecotoxicity of selected adhesive components}

\section{Toxicity}

At room temperature, formaldehyde is a colorless gas with a very characteristic pungent odor. It is very unstable and its chemical reactivity is very high. At concentrations of $1 \mathrm{ppm}\left(1.23 \mathrm{mg} / \mathrm{m}^{3}\right)$ in air, formaldehyde strongly irritates the mucous membranes and eyes, but the threshold concentration that results in eye irritation is much lower, $12 \mu \mathrm{g} / \mathrm{m}^{3}$. It is known that at a concentration of $60 \mathrm{mg} / \mathrm{m}^{3}$ formaldehyde damages pulmonary tissues; chronic obstructive pulmonary disease (COPD) has been diagnosed in employees working for at least five years in particleboard production exposed to an FA concentration of $0.47 \mathrm{mg} / \mathrm{m}^{3}$ in air. Mice exposed to FA concentration of $3.6 \mathrm{mg} / \mathrm{m}^{3}$ for 10 minutes experienced a lowering of their breathing rate by $50 \%$. Pursuant to the acute toxicity data from the PAN Pesticide Database this chemical is considered highly toxic.

FA inhibits reproduction in both animals and humans, causing an increase in the incidence of menstrual disorders, inflammatory diseases of the reproductive tract, and sterility, and increased risk of spontaneous abortion and adverse developmental effects during pregnancy, such as low birth weights among offspring ( Duong et al., 2011; TOXNET Database). It is categorized as a known human carcinogen by the International Agency for Research on Cancer (IARC). It is associated with nasal sinus cancer and nasopharyngeal cancer, brain cancer, prostate cancer, and the development of leukemia, particularly myeloid leukemia. It has been found that the exposure of rats to FA concentrations of 6.8$17 \mathrm{mg} / \mathrm{m}^{3}$ for over 18 months, 6 hours a day and 5 days a week resulted in the formation of nasal cancer. Chromosome aberration and genotoxicity are also observed under FA inhalation. Results of research on FA toxicity are presented in Table 1. The FA lethal dose (LD50) when swallowed is $500 \mathrm{mg} / \mathrm{kg}$ for humans and $800 \mathrm{mg} / \mathrm{kg}$ for rats.

Phenol is a white crystalline solid, soluble in water. It is absorbed into an organism by the respiratory system and through skin contact. The substance has harmful neurotoxic effects on the central nervous system, but also damages the intestines, liver and kidneys. It is considered highly toxic and genotoxic. Retention of phenol vapor in the lungs is as high as $70-80 \%$. The lethal digested dose is $167 \mathrm{mg} / \mathrm{kg}$ for humans and $915 \mathrm{mg} / \mathrm{kg}$ for rats (Safety Data Sheet, NIOSH Database, TOXNET Database).

Benzene, an organic chemical compound and aromatic hydrocarbon, is absorbed by the respiratory system and through skin contact. Its vapor retention in the lungs is $80 \%$. It is accumulated in adipose tissue and has a narcotic effect on humans. It damages bone marrow and weakens the immunological functions. While this substance is considered only slightly toxic according to acute toxicity studies, it is nevertheless a carcinogen which, among other things, causes blood cancer (PAN Pesticide Database). Lethal doses for humans and rats when digested are $500 \mathrm{mg} / \mathrm{kg}$ and $5700 \mathrm{mg} / \mathrm{kg}$, respectively.

Vinyl chloride (VC) is a gas with the sickly sweet odor of chloroform. It is difficult to solve in water and easily polymerizes to polyvinyl chloride. It is absorbed through skin contact and by the respiratory system. The reactive metabolites of vinyl chloride - chloroethylene oxide and chloroacetate aldehyde - react with DNA, acting as mutagens and thus initiating carcinogenesis. VC has narcotic effects, irritates skin and mucous tissues, damages the liver and causes cancer of the lungs, brain and blood. According to acute toxicity data, it is considered only slightly toxic. LC50 for rats is $700 \mathrm{mg} / \mathrm{m}^{3}$.

Styrene is a colorless oily liquid with an irritating, sweet smell. It is poorly soluble in water. It is absorbed by the respiratory system, has neurotoxic properties and can cause depression in humans. It is classified as a mu- 
Table 1. Toxic effects of the exposure to formaldehyde [PAN Pesticide Database, ATSDR 1999]

\begin{tabular}{l|c|c|c|c}
\hline \multicolumn{1}{c|}{ Species } & Route & Parameter & Result & Units \\
\hline Mouse & inhalation & LC50 & 400.0 & $\mathrm{mg} / \mathrm{m}^{3}$ \\
\hline Rat & inhalation & LC50 & 590.0 & $\mathrm{mg} / \mathrm{m}^{3}$ \\
\hline Rabbit & dermal & LD50 & 270.0 & $\mathrm{mg} / \mathrm{kg}$ \\
\hline Mouse & oral & LD50 & 42.0 & $\mathrm{mg} / \mathrm{kg}$ \\
\hline Rat & inhalation $13 \mathrm{wk} 5 \mathrm{~d} / \mathrm{wk} 6 \mathrm{hr} / \mathrm{d}$ & LOAEL $^{*}$ & 3.69 & $\mathrm{mg} / \mathrm{m}^{3}$ \\
\hline Rat & inhalation $13 \mathrm{wk} 5 \mathrm{~d} / \mathrm{wk} 6 \mathrm{hr} / \mathrm{d}$ & NOAEL & 1.23 & $\mathrm{mg} / \mathrm{m}^{3}$ \\
\hline Mouse & inhalation $24 \mathrm{mo} 5 \mathrm{~d} / \mathrm{wk} 6 \mathrm{hr} / \mathrm{d}$ & NOAEL & 2.46 & $\mathrm{mg} / \mathrm{m}^{3}$ \\
\hline Mouse & inhalation $24 \mathrm{mo} 5 \mathrm{~d} / \mathrm{wk} 6 \mathrm{hr} / \mathrm{d}$ & LOAEL & 6.88 & $\mathrm{mg} / \mathrm{m}^{3}$
\end{tabular}

*LOAEL - lowest observed adverse effect level; **NOAEL - no observed adverse effect level

Table 2. Average concentrations of formaldehyde in indoor and outdoor air

\begin{tabular}{|c|c|c|c|c|}
\hline City and country & Environment & $\begin{array}{c}\text { Average concentration } \\
{\left[\mu \mathrm{g} / \mathrm{m}^{3}\right]}\end{array}$ & $\begin{array}{l}\text { Additional } \\
\text { comments }\end{array}$ & Reference \\
\hline \multirow{2}{*}{ Hong Kong, China } & indoor & $\begin{array}{c}18 \\
38 \\
43(20-180)\end{array}$ & $\begin{array}{l}\text { homes, offices } \\
\text { shopping mails } \\
\text { restaurants }\end{array}$ & \multirow{2}{*}{ Lee et al. 2002} \\
\hline & outdoor & $\begin{array}{c}10 \\
19 \\
43(20-130)\end{array}$ & $\begin{array}{l}\text { homes, offices } \\
\text { shopping mails } \\
\text { restaurants }\end{array}$ & \\
\hline $\begin{array}{l}\text { Pinnacles, } \\
\text { Shenandoah National } \\
\text { Park, Virginia, USA }\end{array}$ & outdoor & $\begin{array}{c}1.21 \\
(0.018-3.200)\end{array}$ & rural area & Munger et al. 1995 \\
\hline California, USA & indoor & $\begin{array}{c}43 \\
88.56-95.94\end{array}$ & $\begin{array}{l}\text { homes } \\
\text { mobile homes }\end{array}$ & Sexton et al. 1986 \\
\hline Germany & indoor & 119 & homes & Salthammer et al. 1995 \\
\hline Los Angeles, USA & outdoor & $3.69-52.89$ & & Grosjean 1982 \\
\hline Denver, USA & outdoor & $2.83-4.82$ & & Anderson et al. 1996 \\
\hline Cairo, Egypt & $\begin{array}{l}\text { indoor } \\
\text { outdoor }\end{array}$ & $\begin{array}{l}107.8-130 \\
35.7-45.5\end{array}$ & flats & Khoder et al. 2000 \\
\hline $\begin{array}{l}\text { Isesaki, Japan } \\
\text { Annaka, Japan } \\
\text { Kyoto, Japan } \\
\text { Tokyo, Japan } \\
\text { Niigata, Japan } \\
\text { Miyazaki, Japan }\end{array}$ & outdoor & $\begin{array}{c}3.3-5.4 \\
2.2-5.1 \\
4.0 \\
4.1 \\
2.3 \\
2.4 \\
\end{array}$ & (winter-summer) & Tago et al. 2005 \\
\hline Athens, Greece & outdoor & $9.7-17.2$ & & Bakeas et al. 2003 \\
\hline $\begin{array}{l}\text { Birkenes, Norway } \\
\text { Mace Head, Ireland } \\
\text { Waldhof, Germany } \\
\text { Kosetice, Czech } \\
\text { Donon, France } \\
\text { Ispra, Italy }\end{array}$ & $\begin{array}{l}\text { outdoor } \\
\text { countryside } \\
\text { areas }\end{array}$ & $\begin{array}{l}0.4-1.1 \\
0.5-1.2 \\
0.7-2.0 \\
1.2-2.3 \\
0.8-2.2 \\
2.5-6.5 \\
\end{array}$ & winter-summer & Solberg et al. 2001 \\
\hline
\end{tabular}


tagen, because its oxides form adducts with DNA and proteins. The lethal digested dose (DL50) in rats is $5000 \mathrm{mg} / \mathrm{kg}$. The results of acute toxicity studies classify it as a moderately toxic compound.

There are not many data in the literature concerning the toxicity of adhesive compounds and solvents. Those compounds that have been researched and analyzed are acrylamide (Yang et al., 2005), 2,5-hexanedione (Kihaile et al., 2005), terpenes and aldehydes (Gminski et al., 2010), and resins from conifers (Söderberg et al., 1996).

\section{Ecotoxicity}

The ecotoxicity of adhesive compounds on aquatic organisms has been determined based on mortality rate, growth inhibition, and ontogenesis (PAN Pesticide Database, Safety Data Sheets, NIOSH Database).

Formaldehyde is a compound that is moderately toxic to aquatic organisms. $\mathrm{LC}(\mathrm{EC}) 50$ for the crustacean Daphnia magna is in the range $50-60 \mathrm{mg} / \mathrm{dm}^{3}$. FA does not exert harmful effects on molluscs and zooplankton in concentrations smaller than $100 \mathrm{mg} / \mathrm{dm}^{3}$. For specific fish species, the lowest LC50 values of FA are $2.3 \mathrm{mg} / \mathrm{dm}^{3}$ for white cloud mountain minnows (Tanichthys albonubes) and $22 \mathrm{mg} / \mathrm{dm}^{3}$ for orfe (Leuciscus idus).

Phenol is either not toxic or only slightly toxic to some species of fish, while being highly toxic to other fish species. The LC50 values are in the range of 0.1$500 \mathrm{mg} / \mathrm{dm}^{3}$. For crustaceans, LC50 concentrations are in the range of $0.005-175 \mathrm{mg} / \mathrm{dm}^{3}$.

Benzene is a slightly or moderately toxic compound for aquatic organisms. LC50 concentrations are in the range of $9-425 \mathrm{mg} / \mathrm{dm}^{3}$ (fish), $10-200 \mathrm{mg} / \mathrm{dm}^{3}$ (insects), and $18-373 \mathrm{mg} / \mathrm{dm}^{3}$ (Daphnia magna).

Styrene is toxic to fish Pimephales promelas at a concentration of $4.02 \mathrm{mg} / \mathrm{dm}^{3}$ (LC50/96 h), to the crustacean Daphnia magna at a concentration of $4.7 \mathrm{mg} / \mathrm{dm}^{3}$ (LC50/48 h) and to algae $P_{\text {seudokirchneriella subcapitata }}$ $4.9 \mathrm{mg} / \mathrm{dm}^{3}$ (EC50/72 h). Urea is an easily biodegradable compound and its impact on organisms is insignificant.

\section{Emission of volatile organic compounds}

Adhesives that are widely used in construction (carpentry and joinery) and interior design are the major source of volatile organic compounds in indoor air.

In indoor air, more than 500 different compounds have been identified, including formaldehyde, phenol, resorcinol, benzene, toluene, trimethylbenzene, ethanol, methanol, phenoxyethanol, methyl acetate, ethyl acetate, vinyl acetate, dibuthyl phthalate, acetone, 2-butanone, methylpentane, dimethylpentane, methylhexane, cyclohexanone and methylcyclohexane. These compounds may originate from paints, lacquers, floor coverings, wallpapers and other materials. Croute and coworkers (Croute et al., 2002) noted that painting, staining and lacquering can produce VOC air concentrations of up to $1000 \mathrm{mg} / \mathrm{m}^{3}$. This concentration is a million times higher than typical concentrations in outdoor air (Table 2). Zhu and coworkers (Zhu et al., 1999) analyzed VOC emission from hydrocarbon solvent-based indoor materials used for coating wood surfaces. The analyzed materials were placed in a fume hood with a low ventilation rate to mimic indoor air movement until weight loss was no longer observed. Measurements of the weight loss of the analyzed materials and total VOCs emitted indicated that the initial emission rates were in the range of 186.9$201.2 \mathrm{mg} / \mathrm{h}$ and that $54-57 \%$ of the VOCs contained in the wood material containing polyurethane and organic solvent-based dyes evaporated within 7 hours. Data from China indicate that $27 \%$ of total VOC present in the air results from emissions from industrial plants that use paints and $14 \%$ of total VOC results from emissions from industrial plants that use adhesives (Wei et al., 2008). The use of urea-formaldehyde resins during particleboard production can cause contamination of $7800000 \mathrm{~m}^{3}$ of air per $1 \mathrm{~m}^{2}$ of produced particleboard (dos Santos et al., 2014).

Many factors can impact upon the emission of FA and other VOCs into the air: the type of resin, especially the molar ratio between FA and other compounds in the adhesive, such as urea; the type of wood; condensation rates; water content; type and quality of additions; conditioning methods, and application of external wood coverings. Operational conditions and factors, such as temperature and humidity, efficiency of the air-conditioning system, the use of premises or any interior renovation and equipment restoration may also have a significant impact on VOC emission.

Que and coworkers (2007) analyzed FA and ureaformaldehyde resin emission depending on the molar ratio between FA and urea. They examined the FA-urea molar ratio in the range of $0.97-1.27$. At the hot-pressing temperature of $150^{\circ} \mathrm{C}$ and when the FA-urea molar ratio 
was $1.05, \mathrm{FA}$ emission was E1 quality (the second - middle class in accordance with German standards) $\leq 9 \mathrm{mg} / 100 \mathrm{~g}$. When the FA-urea molar ratio was 1.19 or 1.27, the emission level increased, reaching E2 quality (the third - worst class), which is $9 \mathrm{mg} / 100 \mathrm{~g}<\mathrm{E} 2$ $\leq 30 \mathrm{mg} / 100 \mathrm{~g}$. Currently, there is a tendency to decrease the FA content in urea-formaldehyde resins, while ensuring that the FA-urea molar ratio is $1.1: 1$ or lower.

The FA-urea molar ratio in resins is not the only factor influencing $\mathrm{FA}$ emission. It has been proven that an increase in specific gravity (SG), shelling ratio and pressure augment the FA content in air. It has been shown that a high beech particle content in particleboards results in lower FA emissions than from particleboards consisting of high amounts of pine particles (Nemli and Öztürk, 2006).

Research carried out by Kim and Kim (Kim and Kim, 2005) proved that the addition of melamine-formaldehyde resin to urea-formaldehyde resin dramatically reduced the level of formaldehyde emission from wood fiber made from Korean pine (Pinus densiflora). Urea-formaldehyde resin produces approximately $23 \%$ more emissions of formaldehyde than melamine-urea-formaldehyde resin (Silva et al. 2015). A decrease in FA emissions can also be achieved using polymeric $4,4^{\prime}$-methylene diphenyl isocyanate (PDMI) and phenol-formaldehyde (PF) resins to manufacture particleboard from recycled woodwaste chips for use in indoor environments. The research showed that formaldehyde emissions decreased linearly with an increasing PMDI/PF particle ratio. FA emissions were below $0.3 \mathrm{mg} / \mathrm{dm}^{3}$ when the weight percentage of PMDI/particles was 7:3 (Wang et al., 2007). Lignocellulosic ethanol residue (a by-product of lignocellulosic ethanol production) may be used as a valuable resource to partially replace phenol (in the range of 10$70 \%$ ) in the preparation of lignin-phenol-formaldehyde adhesive (Zhang et al., 2013). Ghaffar and Fan (Ghaffar and Fan, 2014) used lignin from straw to form phenolformaldehyde resins for plywood, particleboard and other composites.

Some finishing treatment methods for wood products, such as their coating with paints, foils, laminates and veneer used to reduce water adsorption, may decrease FA and VOC emissions. Surface materials such as vinyl films or melamine impregnation reduce the FA emissions from wood based products. However, total VOC (TVOC) emissions of the coated materials can be higher, because the finishing materials (such as urethane and lacquer) emit their own VOCs. However, Kim and coworkers (Kim et al., 2010) proved that PVC appeared to be a very efficient coating material, reducing both FA and VOC emissions.

The amount of FA and VOC emissions also depends on the manufacturing technology, such as open-mold and closed-mold processes. Di Tomasso and coworkers (Di Tomasso et al., 2014) noted that open-mold gelcoating used in the manufacture of fiber-reinforced polymer matrix composites produced high amounts of styrene to be used as a linking agent for the unsaturated polyester resins. The closed-mold technologies reduced the measured styrene levels from $28-70 \mathrm{ppm}$ to 0.23 $0.37 \mathrm{ppm}$. Closed-mold gel-coating is a route to reducing the environmental impact of VOCs (Rogers et al., 2014).

A very important issue in the assessment of FA emissions is the proper monitoring of emissions from a variety of wood products (Böhm et al., 2012; Marć et al., 2012). Guo and coworkers (Guo et al., 2002) proved that the total VOC concentration from wood products was in the range $18-408 \mu \mathrm{g} / \mathrm{m}^{3}$ in indoor air, including emissions of $34-352 \mu \mathrm{g} / \mathrm{m}^{2} / \mathrm{h}$ from hardboards, $88 \mu \mathrm{g} / \mathrm{m}^{2} / \mathrm{h}$ from particleboards and $65 \mu \mathrm{g} / \mathrm{m}^{2} / \mathrm{h}$ from plywood. Guo et al. (2002) demonstrated typical FA and TVOCs emissions from different types of materials (Table 3 ). The differences in emission rates are caused by the types of wood, adhesives and resins and the applied measurement methods.

Table 3. Typical FA and TVOC emission rates from selected wood materials

\begin{tabular}{l|c|c}
\hline \multirow{2}{*}{\multicolumn{1}{c|}{ Material }} & \multicolumn{2}{c}{$\begin{array}{c}\text { Emission rate } \\
{\left[\mu \mathrm{g} / \mathrm{m}^{2} / \mathrm{h}\right]}\end{array}$} \\
\cline { 2 - 3 } & FA & TVOC \\
\hline Medium-density fibreboard & $733-2292$ & - \\
\hline Hardwood plywood panelling & $62.5-1417$ & $34-352$ \\
\hline Particleboard & $83-1042$ & 88 \\
\hline Softwood plywood & $10-30$ & 65 \\
\hline
\end{tabular}

Among many factors influencing the emission of organic compounds from wood, it is temperature, humidity and the air exchange rate that play significant roles. Lin and coworkers (Lin et al., 2009) tested wooden flooring composites made from hardwood and plywood. Within six days, when the room temperature had increa- 
sed from $15^{\circ} \mathrm{C}$ to $30^{\circ} \mathrm{C}$, the specific VOC emission rate increased 1.5-129-fold. An increase in humidity from 50\% to $80 \%$ resulted in VOC concentrations and emission rates increases of up to 32 -fold. When the air exchange rate increased from 1 to 2 per hour, VOC concentrations decreased by $9-40 \%$ and the specific VOC emission rates increased by $6-98 \%$.

An and coworkers (An et al., 2010) measured FA and VOC emissions from flooring with an adhesive (melamine-urea-formaldehyde resin). The flooring heating system was constructed with MDF with a bottom panel, heater sheet and engineered flooring. An oven dryer with a fan was used for the air circulation system. The floor surface temperatures were set to $20^{\circ} \mathrm{C}, 26^{\circ} \mathrm{C}$ and $32{ }^{\circ} \mathrm{C}$, respectively. The rate of $\mathrm{FA}$ emissions from the flooring was the highest when the temperature was $32^{\circ} \mathrm{C}$, and then it decreased with time. The flooring emitted benzene, toluene, ethylbenzene and xylene, as well as other, unidentified VOCs. Sampling emission rates using different indoor heating systems (floor heating systems both with and without an air circulation system) showed higher FA emission rates when floor heating lacked an air circulation system, while VOC emission rates were higher when the floor heating had an air circulation system. FA and VOC emission rates from engineered flooring depend on the temperature of floor heating and air circulation. Table 4 presents the differences in FA and TVOC emission rates from engineered flooring depending on the length of time when the air is circulated and floor is heated. TVOC emission rates from engineered flooring with adhesives was higher when an air circulation system was applied than in the case of a floor heating system.

There are several types of wood flooring, including solid wood flooring, laminate wood flooring with highdensity fiberboard (HDF) as the core material, and engineered flooring. Engineered flooring consists of plywood with a thin veneer bonded to the face of the plywood using melamine-formaldehyde and/or urea-formaldehyde resins as hot-press adhesives. Further research by An and coworkers (An et al., 2011) showed that FA emissions from laminate flooring were the highest at the temperature of $32^{\circ} \mathrm{C}$. Flooring with a floor heating system emitted more FA than an air circulation system. The VOC emission rate was higher with an air circulation system than with floor heating without air circulation.
Wiglusz and coworkers (Wiglusz et al., 2002) compared $\mathrm{FA}$ and VOC emission rates at various temperatures $-23^{\circ} \mathrm{C}, 29^{\circ} \mathrm{C}$ and $50^{\circ} \mathrm{C}$ - from two types of laminate flooring: a bonded laminate on top of a particleboard substrate (A); and thermofused saturated papers on top of a high density fiber substrate (B). At lower temperatures, no FA emission was detected while the VOC emission rate was low. At $50^{\circ} \mathrm{C}$, flooring A showed high initial FA and VOC emissions, which then decreased with time. However, an increase in temperature did not increase VOC emissions from type B flooring. The results showed that the chemical composition of the laminate flooring, together with the level of floor heating, contributed to the contamination of indoor air.

The VOC emission rate depends on the quality of buildings. Guo and coworkers (Guo et al., 2002) described literature data which show that average VOC concentrations in indoor air in buildings were $1130 \mu \mathrm{g} / \mathrm{m}^{3}$. In new buildings, concentrations could be as high as $4000 \mu \mathrm{g} / \mathrm{m}^{3}$; in newly renovated properties, concentrations were $19565 \mu \mathrm{g} / \mathrm{m}^{3}$ after $1520 \mathrm{~h}$, but then decreased to $11 \mu \mathrm{g} / \mathrm{m}^{3}$ after $2550 \mathrm{~h}$. The largest contribution to the VOC concentration was from the air ventilation system (39\%), and then from inhabitants' activities (37.3\%) and the building materials (23.7\%). Table 5 presents differences in TVOC emission rates from office buildings, based on research by Zuraimi and coworkers (Zuraimi et al., 2004).

It is assumed that a reduction in VOC emissions can be achieved by using construction materials tested for air pollutant emission and maximum air exchange rate, and by reducing the use of materials requiring adhesives. Guo and coworkers (Guo et al., 2003) showed that in houses with a high air exchange rate (those with efficient ventilation) and built using construction materials with low VOC emission rates, the VOC emission rate is in a range from 0 to $43 \mu \mathrm{g} / \mathrm{m}^{3}$. The published data show that average emission levels in new buildings in Nordic countries and in the USA range from 0.48 to $31.7 \mathrm{mg} / \mathrm{m}^{3}$. In Paris, 61 flats were tested for the presence of aldehydes in indoor air. The pollution levels depended on the time of renovation, the age of wall and floor coverings, cooking, smoking, temperature, humidity and carbon dioxide levels. The average FA concentration in rooms in Paris dwellings was $34.4 \mu \mathrm{g} / \mathrm{m}^{3}$, acetaldehyde concentration $10.7 \mu \mathrm{g} / \mathrm{m}^{3}$, and hexanal and 
Table 4. FA and VOC emission rates from engineered flooring depending on the temperature of floor heating and air circulation

\begin{tabular}{|c|c|c|c|c|}
\hline \multirow[t]{2}{*}{ Compounds } & \multirow[t]{2}{*}{ System } & \multicolumn{3}{|c|}{$\begin{array}{c}\text { Emission rate after } 1 \text { day and after } \rightarrow 7 \text { days } \\
\text { at the set temperature of: } \\
{[\mu \mathrm{g} / \mathrm{m} 2 / \mathrm{h}]}\end{array}$} \\
\hline & & $20^{\circ} \mathrm{C}$ & $26^{\circ} \mathrm{C}$ & $32^{\circ} \mathrm{C}$ \\
\hline \multirow{2}{*}{ FA } & air circulation system & $63 \rightarrow 22$ & $75 \rightarrow 30$ & $105 \rightarrow 42$ \\
\hline & floor heating system & $60 \rightarrow 28$ & $110 \rightarrow 45$ & $179 \rightarrow 49$ \\
\hline \multirow{2}{*}{ TVOC's } & air circulation system & $430 \rightarrow 200$ & $580 \rightarrow 210$ & $70 \rightarrow 220$ \\
\hline & floor heating system & $380 \rightarrow 100$ & $410 \rightarrow 250$ & $610 \rightarrow 280$ \\
\hline
\end{tabular}

Table 5. Differences in TVOC emission rates from office buildings in Singapore depending on the air conditioning system and personnel activities [Zuraimi et al., 2004]

\begin{tabular}{l|c}
\hline \multicolumn{1}{c|}{ Place of measurement } & $\begin{array}{c}\text { TVOC emission rates } \\
{\left[\mu \mathrm{g} / \mathrm{m}^{2} / \mathrm{h}\right]}\end{array}$ \\
\hline Construction materials & $1462-7883$ \\
\hline Air conditioning systems without personnel present & $1336-14732$ \\
\hline Air conditioning systems with personnel present & $1601-15629$ \\
\hline
\end{tabular}

pentanal were $33.5 \mu \mathrm{g} / \mathrm{m}^{3}$ and $8.9 \mu \mathrm{g} / \mathrm{m}^{3}$, respectively (Clarisse et al., 2003).

Based on the measurements of six PVC materials and four adhesives, Järnström and coworkers (2008) showed that individual materials had significantly lower VOC emissions and ammonia emission rates than the complete constructions. The permeability of the PVC products for VOCs and the type of adhesive used in the product affected the VOC emission rates of the individual PVC materials.

In homes, FA and VOCs are emitted not only from flooring, walls, adhesives and covering materials, but also from paints. Kim and coworkers (Kim et al., 2011) measured VOC and FA emissions from oil-based paints, emulsion paints and water-dispersion paints. The emission rate depended on the amount of paint needed to coat walls, and this was higher for coatings of $300 \mathrm{~g} / \mathrm{m}^{2}$ than $121 \mathrm{~g} / \mathrm{m}^{2}$. The FA emission rate was low. The VOC emission rate was much higher for oil-based paint than for emulsion paints and water-dispersion paints.

The problem of setting an appropriate indoor air exposure limit for formaldehyde is currently widely discussed in the literature. In the EU, the indoor exposure limit has been based on nose and throat irritation thresholds of $0.1 \mathrm{mg} / \mathrm{m}^{3}$ (0.08 ppm; LOAEL), NOAEL of
$0.03 \mathrm{mg} / \mathrm{m}^{3}(0.025 \mathrm{ppm})$ and an assessment factor of 30 , including a factor of 3 for the higher sensitivity of children. The threshold for sensory irritation is $1 \mathrm{ppm}$, which is a higher concentration than the nose and throat irritation thresholds of $0.1 \mathrm{mg} / \mathrm{m}^{3}$. Arts and coworkers (Arts et al., 2008) proposed an FA concentration of 0.1 $\mathrm{ppm}\left(0.12 \mathrm{mg} / \mathrm{m}^{3}\right)$ as a safe and appropriate indoor air level. This concentration is 100 -fold higher than the safe exposure concentration advised by the European Commission $\left(1 \mu \mathrm{g} / \mathrm{m}^{3}\right)$. It is worth mentioning that the EC's indoor air limit for FA is lower than the FA levels generally encountered in the atmospheric air in many European countries, which are in the range of $1.3-17.2 \mu \mathrm{g} / \mathrm{m}^{3}$. The indoor air limit for TVOCs depends on the country, e.g. $300 \mu \mathrm{g} / \mathrm{m}^{3}$ (Germany) and $500 \mu \mathrm{g} / \mathrm{m}^{3}$ (Australia) (Table 6). Similarly, there are different legal limits for VOC and formaldehyde emissions from interior construction products into indoor air, which usually apply after 28 days of storage in a ventilated test chamber. TVOC concentrations differ from $20 \mu \mathrm{g} / \mathrm{m}^{3}$ (Finland) to $>2000 \mu \mathrm{g} / \mathrm{m}^{3}$ (French regulations class $\mathrm{C}$ ) and FA concentrations from $10 \mu \mathrm{g} / \mathrm{m}^{3}$ (Finland, French regulations class $\mathrm{A}+$ ) to $>120 \mu \mathrm{g} / \mathrm{m}^{3}$ (French regulations class $\mathrm{C}$ ) (Eurofins Scientific, 2015). 
Table 6. Comparison of the regulation and guidelines concerning formaldehyde pertinent

to indoor environments [ASHRAE Standard 2010]

\begin{tabular}{l|c}
\hline Organisation & $\begin{array}{c}\text { Air concentration in average time } \\
\text { of } 8 \text { hours } \\
\text { [ppm] }\end{array}$ \\
\hline \multicolumn{2}{c}{ Enforceable and regulatory levels } \\
\hline OSHA & $\begin{array}{c}0.75 \\
(15 \mathrm{~min})^{*}\end{array}$ \\
\hline MAK & $\begin{array}{c}0.3 \\
\text { Canadian }\end{array}$ \\
\hline WHO/Europe & $0.081\left(0.1 \mathrm{mg} / \mathrm{m}^{3}\right)(30 \mathrm{~min})^{*}$ \\
\hline NIOSH & 0.016 \\
& $0.1 \mathrm{ppm}(15 \mathrm{~min})^{*}$ \\
\hline
\end{tabular}

* Numbers in brackets refer to averaging times less than 8 hours

Current scientific research is focused mostly on methods for reducing FA emissions from adhesives, including the widely applied urea-formaldehyde resins. Boran and coworkers (Boran et al., 2011) analyzed the effect on the FA emission rates from MDF panels of adding different amine compounds to UF resin. The addition of cone particles from stone pine improved the water resistance of the panels and reduced FA emissions from urea-formaldehyde resins (Buyuksari et al., 2010). Çetin and Özmen (Çetin and Özmen, 2002) observed that the partial substitution of phenol with lignin in phenol-formaldehyde resins does not affect their physical properties.

Lee (Lee, 2012) developed a procedure for producing a nano-sized, porous UF polymer powder which did not generate formaldehyde. Kim (Kim, 2010) proposed a method of reducing FA and VOC emissions from woodbased flooring by using a green adhesive based on a cashew nut shell liquid (CNSL). Jang and coworkers (Jang et al., 2011) suggested that formaldehyde-free adhesives could be produced using renewable materials, such as soybean. The so y-based adhesive developed by Jang et al. consists mainly of soy flour and a small amount of polyamidoamine-epichlorohydrin resin as a curing agent.

In parallel to the development of new adhesives, intense research is being carried out on resin modification, including urea-formaldehyde resin. Park and Jeong (Park and Jeong, 2011) published a study investigating the relationship between the hydrolytic stability and the crystalline regions of cured UF resins with different FAurea mole ratios to better understand the hydrolysis of cured UF resin adhesives responsible for FA emissions in service.

\section{Treatment of wastewater from the production of formaldehyde-based resin adhesives}

A very important issue in the impact assessment of formaldehyde-based resin adhesives on the environment is the treatment of wastewater derived from their production. Wastewater from the production of adhesives contains high concentrations of both base substances and additional organic compounds. Many of these pollutants are characterized by high ecotoxicity and resistance to biodegradation. FA concentrations detected in effluents are in the range of $100-10000 \mathrm{mg} / \mathrm{dm}^{3}$ (Guimarães et al., 2012), and sometimes even higher, up to $30000 \mathrm{mg} / \mathrm{dm}^{3}$ (Herrera Melián et al., 2008). Similarly, phenol may be present in raw wastewater in high concentrations, up to $60 \mathrm{~g} / \mathrm{dm}^{3}$ (Agarwal et al., 2009). Garrido and coworkers (Garrido et al., 2001) noted that wastewater from formaldehyde-urea adhesive factories can contain $4000 \mathrm{mg} \mathrm{FA} / \mathrm{dm}^{3}$ and urea concentrations can be up to $805 \mathrm{mg}$ TKN (Total Kjeldahl Nitrogen) $/ \mathrm{dm}^{3}$. Due to the high toxicity of phenol, wastewater containing this compound in concentrations higher than $60 \mathrm{~g} / \mathrm{dm}^{3}$ should be chemically pre-treated, e.g. in an extraction process. Industrial wastewater can be first treated in a local chemical pre-treatment plant and then discharged to a sewer system.

FA, phenol and ammonia concentrations in treated wastewater (data from Poland) should not exceed $2 \mathrm{mg} / \mathrm{dm}^{3}, 0.1 \mathrm{mg} / \mathrm{dm}^{3}$ and $10 \mathrm{mg} / \mathrm{dm}^{3}$, respectively. Therefore, it is necessary to use treatment technologies that remove the pollutants to the level required by law. To eliminate pollutants from wastewater, biological or chemical methods (or a combination of the two) are used.

Formaldehyde is easily biodegraded both in aerobic and anaerobic conditions, if its concentration does not inhibit metabolic activities of microorganisms participating in the wastewater treatment. Tister and ZagorcKoncan (Tister and Zagorc-Koncan, 1997) proved that EC50 for FA inhibiting microbial respiration in wastewater was $34.1 \mathrm{mg} / \mathrm{dm}^{3}$. Other studies indicate that FA biodegradation occurs in higher concentrations following 
the adaptation of microorganisms. Effective 99.5\% FA removal using activated sludge was reported by Eiroa et al. (Eiroa et al., 2005). The initial FA concentration in the raw wastewater was $3168 \mathrm{mg} / \mathrm{dm}^{3}$. Łebkowska and coworkers (Łebkowska et al., 2011) obtained 55\% FA removal from wastewater containing $2880 \mathrm{mg} \mathrm{FA} / \mathrm{dm}^{3}$ using activated sludge. Eiroa and coworkers (Eiroa et al., 2004) used a denitrifying granular sludge blanket reactor to treat wastewater with an initial FA concentration of $5000 \mathrm{mg} / \mathrm{dm}^{3}$. The efficiency of the process was $99.5 \%$.

In aerobic conditions, microorganisms oxidize formaldehyde to formic acid and methanol and then to $\mathrm{CO}_{2}$ and $\mathrm{H}_{2} \mathrm{O}$. Due to the high level of toxicity of FA, if it is present in high concentrations in wastewater, enzymatic detoxification must be carried out to enable its use as a source of carbon and energy. Mitsui et al. (Mitsui et al., 2005) investigated the cultivation of a methylotrophic strain, Methylobacterium sp. MF1, and proved that detoxification and growth on extracellular FA requires not only enzymes related to oxidation and assimilation of this compound, but also a means of its transfer inside the cells without damaging cell membranes. Herrera Melián and coworkers (Herrera Melián et al., 2008) showed that an application of combined aerated biological filters and wetland reactors resulted in an almost complete removal of the high FA concentration from wastewater and in wastewater detoxification, which indicated that no toxic intermediates were formed.

Biodegradation of formaldehyde can be carried out in aerobic conditions, but the application of anaerobic and combined aerobic-anaerobic processes is also possible. Kaczala et al. (Kaczala et al., 2010) constructed a biological system consisting of a lab-scale anaerobicintermittently aerated reactor. The authors achieved $65 \%$ removal of COD (Chemical Oxygen Demand) and 93\% FA elimination; nitrification and denitrification processes were carried out simultaneously. As an alternative to aerobic methods of wastewater treatment, Priya et al. (Priya et al., 2009) used an upflow anaerobic fixed film reactor (UAFB) to eliminate FA from wastewater.

The treatment of wastewater from phenol-formaldehyde resin production was investigated by Moussavi et al. (Moussavi et al., 2010). They proposed a novel moving-bed sequential continuous-inflow reactor (MSCR) to degrade wastewater containing high concentrations of phenol and formaldehyde (each at concentrations of $1300 \mathrm{mg} / \mathrm{dm}^{3}$ ). An over $97 \%$ reduction of both com- pounds was noted when the loading rates were $1.2 \mathrm{~kg} /\left(\mathrm{m}^{3} \cdot \mathrm{d}\right)$ for each compound.

Lofty and Rasched (Lofty and Rasched, 2002) observed that in wastewater from phenol-formaldehyde resin production, phenol had a toxic impact on biochemical reactions and its transformation was inhibited by the presence of FA. They proposed the addition of sodium sulfite which reacts with FA forming sodium formaldehyde bisulfite, a biodegradable substance which is nontoxic to microorganisms.

Due to the toxic characteristics of wastewater from resin production, some attempts to apply advanced oxidation processes (AOPs), usually prior to biological treatment, have been made. Guimarães et al. (Guimarães et al., 2012) investigated FA degradation in a water solution $\left(400-1200 \mathrm{mg} / \mathrm{dm}^{3}\right)$ by photolysis and AOP processes - UV/ $\mathrm{H}_{2} \mathrm{O}_{2}$, Fenton process and photo-Fenton process. AOPs resulted in the removal of $98 \% \mathrm{FA}$ and $65 \% \mathrm{DOC}$ from the solution.

To eliminate phenolic compounds from wastewater generated during alkydic resin production, Schwingel de Oliveira et al. (Schwingel de Oliveira et al., 2007) used Fenton and photo-Fenton processes. The best results were obtained with the photo-Fenton process assisted with solar radiation, and this resulted in the removal of 99.5\% COD, 99.1\% TOC and 95\% phenols.

Combining AOPs and biological methods to treat wastewater containing FA has proved to be effective in the removal of high concentrations of pollutants. Moussavi et al. (Moussavi et al., 2009) showed that the efficiency of the catalytic advanced oxidation process (CAOP) of $\mathrm{O}_{3} / \mathrm{MgO} / \mathrm{H}_{2} \mathrm{O}_{2}$ was $79 \%$ in $\mathrm{FA}$ removal and $65.5 \%$ in COD removal for a solution with an initial FA concentration of $7000 \mathrm{mg} / \mathrm{dm}^{3}$. Post-treatment in an SBR (Sequencing Batch Reactor) system with a total cycle time of $24 \mathrm{~h}$ resulted in complete FA removal and a $98 \%$ reduction of COD; the COD concentration in the effluent was below $60 \mathrm{mg} / \mathrm{dm}^{3}$.

Aparicio et al. (Aparicio et al., 2007) analyzed the ozonation process of wastewater from a resin-producing factory and, afterwards, the biodegradability of the ozonated effluent was studied under anoxic conditions. It was proved that a combined post-ozonation and biological treatment can be applied to recalcitrant wastewater from a resin-producing factory. The ozonation step enhances the biodegradability of wastewater compounds. 
It should be noted that the wastewater treatment efficiency cannot be based on FA removal alone. Other parameters such as $\mathrm{BOD}_{5}$ (Biochemical Oxygen Demand), COD, TOC (Total Organic Carbon) and TKN should also be considered to determine the quality of treated wastewater and its environmental safety.

\section{Treatment of waste products and serviced woods}

Environmental protection problems arising from the use of resin-based adhesives also include the treatment and disposal of waste products that contain adhesives. Wood and wood waste may contain not only resin-based adhesives, but also paint, surface coatings, coverings and natural oils, toxic compounds in wood preservatives, insecticides, antibacterial and antifungal agents, such as arsenic compounds or creosote, tebuconazole, propiconazole, cyfluthrin and alkyd resins. Research on the leaching of those compounds to water from impregnated wood proved their high toxicity for water biocenoses (Łebkowska et al., 2003). Biological treatment of wastewater containing wood preservatives, e.g. from a sawmill, has been scarcely investigated in the literature; advanced oxidation processes are recommended for its decontamination (Munoz et al., 2014). The removal of these pollutants from wastewater usually requires a multi-step treatment and a careful choice of treatment methods to ensure that pollutant levels are not greater than the legally permitted concentrations.

Singh and Singh (Singh and Singh, 2014) stated that it is possible to use wood-rotting fungi for the removal of toxic compounds from treated and serviced wood. The wood can then be processed to generate fibers for biocomposites and chemicals such as lignin degradation products as antioxidants or adhesives. In Germany, only $26 \%$ of the recovered wood is suitable for re-use (Höglmeier et al., 2013).

One of the main methods of disposing waste wood is combustion. This may lead to emissions of polychlorinated dibenzo-p-dioxins (PCDDs) and polychlorinated dibenzofurans (PCDFs). PCDDs and PCDFs are formed via precursors such as phenols and lignins during reactions with chlorine. The highest concentrations of dioxins are noted from the combustion of ammonium chloride hardened plywood or PVC-coated plywood. Measurement of PCDD and PCDF emissions showed that their concentrations in air ranged from 0.005 to $4 \mathrm{ng}$
I-TEQ (International Toxic Equivalents) $/ \mathrm{m}^{3}$ (Lavric et al., 2004).

It should be noted that during combustion natural wood may also emit dioxins in concentrations above the legal threshold $\left(0.1 \mathrm{I}-\mathrm{TEQ} / \mathrm{m}^{3}\right)$. It has been shown that the total amounts of PCDDs and PCDFs in plywood combustion gasses are in the range of $35-529 \mathrm{ng} / \mathrm{Nm}^{3}$, and are higher from plywood made using softwood trees than those using broadleaf ones (Muto and Sugawara, 2001).

$\mathrm{PCB}$ emissions have been measured during the combustion of wood samples from radiate pine, camphor laurel, chipboards and MDF (Bhargava et al., 2002). MDF contained phenol, resorcinol or cresol, formaldehyde, urea or melamine. Chipboard contained bonding agents, such as phenolic and urea resins. PCB emission rates for camphor laurel, MDF and chipboard were 17, 40 , and $48 \mu \mathrm{g} / \mathrm{kg}$ of wood, respectively.

\section{Conclusions}

Adhesives based on formaldehyde are a source of many pollutants which negatively impact upon both human and animal health and the environment. Wastewater and wastes from their production cause a lot of problems and require the application of specific methods for their elimination. In recent years, significant progress has been made in the development and production of adhesives, especially in limiting the concentration of formaldehyde and other harmful/toxic compounds. In terms of environmental protection, a very attractive option is to produce adhesives from renewable materials. Also, new wood coatings have been proposed and developed that reduce $\mathrm{VOC}$ emissions to indoor air. Moreover, new methods to treat wastewater from adhesive resin production have been proposed, and these may enable the efficient removal of harmful pollutants from the aquatic environment.

\section{References}

Agarwal S., Ferreira A.E., Reis M.T.A., Ismael M.R.C., Ferreira L.M., Machado R.M., Carvalho J.M.R. (2009) A study on a combined process for the treatment of phenolic resin plant effluents. J. Hazard. Mater. 169: 659-666.

Agency for Toxic Substances and Disease Registry (1999) Formaldehyde Toxic Profile. http://www.atsdr.cdc.gov/ toxprofiles/tp.asp?id $=220 \&$ tid $=39$

American Society of Heating, Refrigerating and Air-Conditioning Engineers, Inc. (2010) Ventilation for acceptable indoor air quality. ASHRAE Standard. Atlanta. 
An J.-Y., Kim S., Kim H.-J. (2011) Formaldehyde and TVOC emission behavior of laminate flooring by structure of laminate flooring and heating condition. J. Hazard. Mater. 187: 44-51.

An J.-Y., Kim S. Kim H.-J., Seo J. (2010) Emission behavior of formaldehyde and TVOC from engineered flooring in under heating and air circulation systems. Build. Environ. 45: 1826-1833.

Anderson L.G., Lanning J.A., Barrell R., Miyagishima J., Jones R.H., Wolfe P. (1996) Sources and sinks of formaldehyde and acetaldehyde: an analysis of Denver's ambient concentration data. Atmos. Environ. 30(12): 2113-2123.

Aparicio M.A., Eiroa M., Kennes C., Veiga M.C. (2007) Combined post-ozonation and biological treatment of recalcitrant wastewater from a resin-producing factory. J. Hazard. Mater. 143: 285-290.

Arts J.H.E., Muijser H., Kuper C.F., Woutersen R.A. (2008) Setting an indoor air exposure limit for formaldehyde: factors of concern. Regul. Toxicol. Pharm. 52: 189-194.

Bakeas E.B., Argyris D.I., Siskos P.A. (2003) Carbonyl compounds in the urban environment of Athens, Greece. Chemosphere 52: 805-813.

Bhargava A., Dlugogorski B.Z., Kennedy E.M. (2002) Emission of polyaromatic hydrocarbons polychlorinated biphenyls and polychlorinated dibenzo-p-dioxins and furans from fires of wood chips. Fire Safety J. 37: 659-672.

Böhm M., Salem M.Z.M., Srba J. (2012) Formaldehyde emission monitoring from a variety of solid wood plywood blockboard and flooring products manufactured for building and furnishing materials. J. Hazard. Mater. 221-222: 68-79.

Boran S., Usta M., Gümüşkaya E. (2011) Decreasing formaldehyde emission from medium density fiberboard panels produced by adding different amine compounds to urea formaldehyde resin. Int. J. Adhes. Adhes. 31: 674-678.

Buyuksari U., Ayrilmis N., Avci E., Koc E. (2010) Evaluation of the physical mechanical properties and formaldehyde emission of particleboard manufactured from waste stone pine (Pinus pinea L.) cones. Bioresource Technol. 101: 255-259.

Çetin N.S., Özmen N. (2002) Use of organosolv lignin in phenol-formaldehyde resins for particleboard production: I. Organosolv lignin modified resins. Int. J. Adhes. Adhes. 32: 481-486.

Clarisse B., Laurent A.M., Seta N., Le Moullec Y., El Hasnaoui A., Momas I. (2003) Indoor aldehydes: measurement of contamination levels and identification of their determinants in Paris dwellings. Environ. Res. 92: 245-253.

Croute F., Poinsot J., Gaubin Y., Beau B., Simon V., Murat J.C., Soleilhavoup J.P. (2002) Volatile organic compounds cytotoxicity and expression of HSP72 HSP90 and GRP78 stress proteins in cultured human cells. Biochim. Biophys. Acta 1591: 147-155.

Di Tomasso C., Gombos Z.J., Summerscales J. (2014) Styrene emissions during gel-coating of composites. J. Clean. Production 83: 317-328. dos Santos M.F.N., Rosane Ap G.B., Bezerra B.S., Varum H.S. (2014) Comparative study of the life cycle assessment of particleboards made of residues from sugarcane bagasse (Saccharum spp.) and pine wood shavings (Pinus elliottii). J. Clean. Production 64: 345-355.

Duong A., Steinmaus C., McHale C.M., Vaughan C.P., Zhang L. (2011) Reproductive and developmental toxicity of formaldehyde: a systematic review. Mutat Res. 728(3): 118-138.

Eiroa M., Kennes C., Veiga M.C. (2004) Formaldehyde and urea removal in a denitrifying granular sludge blanket reactor. Water Res. 38: 3495-3502.

Eiroa M., Kennes C., Veiga M.C. (2005) Simultaneous nitrification and formaldehyde biodegradation in an activated sludge unit. Bioresource Technol. 96: 1914-1918.

Eurofins Scientific (2015) Summary of European VOC limits (example). www.eurofins.com

Garrido J.M., Méndez R., Lema J.M. (2001) Simultaneous urea hydrolysis formaldehyde removal and denitrification in a multified upflow filter under anoxic and anaerobic conditions. Water Res. 35 (3): 691-698.

Ghaffar S.H., Fan M. (2014) Lignin in straw and its applications as an adhesive. Int. J. Adhes. Adhes. 48: 92-101.

Gminski R., Tang T., Mersch-Sundermann V. (2010) Cytotoxicity and genotoxicity in human lung epithelial A549 cells caused by airborne volatile organic compounds emitted from pine wood and oriented strand boards. Toxicol. Lett. 196: 33-41.

Grosjean D. (1982) Formaldehyde and other carbonyls in Los Angeles ambient air. Environ. Sci. Technol. 16: 254-262.

Guimarães J.R., Turato Farah C.R., Guedes Maniero M., Fadini P.S. (2012) Degradation of formaldehyde by advanced oxidation processes. J. Environ. Manage. 107: 96-101.

Guo F., Murray F., Lee S.-C. (2002) Emissions of total volatile organic compounds from pressed wood products in an environmental chamber. Build. Environ. 37: 1117-1126.

Guo H., Murray F., Lee S.C. (2003) The development of low volatile organic compound emission house - a case study. Build. Environ. 38: 1413-1422.

Herrera Melián J.A., Ortega Méndez A., Araña J., Gonzáles Díaz O., Tello Rendón E. (2008) Degradation and detoxification of formalin wastewater with aerated biological filters and wetland reactors. Process Biochem. 43: 1432-1435.

Höglmeier K., Weber-Blaschke G., Richter K. (2013) Potentials for cascading of recovered wood from building deconstruction - a case study for south-east Germany. Resours. Conserv. Rec. 78: 81-91.

Jang Y., Huang J., Li K. (2011) A new formaldehyde-free wood adhesive from renewable materials. Int. J. Adhes. Adhes. 31: 754-759.

Järnström H., Saarela K., Kalliokoski P., Pasanen A.-L. (2008) Comparison of VOC and ammonia emissions from individual PVC materials adhesives and from complete structures. Environ. Int. 34: 420-427.

Kaczala F., Marques M., Hogland W. (2010) Biotreatability of wastewater generated during machinery washing in 
a wood-based industry: COD formaldehyde and nitrogen removal. Bioresource Technol. 101: 8975-8983.

Khoder M.I., Shakour A.A., Farag S.A., Hameed A.A. (2000) Indoor and outdoor formaldehyde concentrations in homes in residential areas in Greater Cairo. J. Environ. Monitoring 2(2): 123-126.

Kihaile P.E., Aoki K., Kimura N., Pei W., Misumi J. (2005) Are sperm parameters the best indicator of 25-hexanedione reproductive toxicity in male rats? Reprod. Toxicol. 20: 515-519.

Kim J.A., Kim S., Kim H.-J., Kim Y.S. (2011) Evaluation of formaldehyde and VOC emission factors from paints in a small chamber: the effects of preconditioning time and coating weight. J. Hazard. Mater. 187: 52-57.

Kim K.-W., Kim S., Kim H.-J., Park J.C. (2010) Formaldehyde and TVOC emission behaviors according to finishing treatment with surface materials using $20 \mathrm{~L}$ chamber and FLEC. J. Hazard. Mater. 177: 90-94.

Kim S., Kim H.-J. (2005) Comparison of standard methods and gas chromatography method in determination of formaldehyde emission from MDF bonded with formaldehydebased resins. Bioresource Technol. 96: 1457-1464.

Kim S. (2010) The reduction of formaldehyde and VOCs emission from wood-based flooring by green adhesive using cashew nut shell liquid. J. Hazard. Mater. 182: 919-922.

Lavric E.D., Konnov A.A., De Ruyck J. (2004) Dioxin levels in wood combustion - a review. Biomass Bioenerg. 26: 115145.

Lee S.-C, Guo H., Li W.-M., Chan L.-Y. (2002) Inter-comparison of air pollutant concentrations in different indoor environments in Hong Kong. Atmos. Environ. 36: 19291940.

Lee C.-T. (2012) Preparation of porous nano-sized ureaformaldehyde polymer powder. J. Ind. Eng. Chem. 18: 918-925.

Lin C.-C., Yu K.-P., Zhao P., Lee G.W.-M. (2009) Evaluation of impact factors on VOC emissions and concentrations from wooden flooring based on chamber tests. Build. Environ. 44: 525-533.

Lofty H.R., Rashed I.G. (2002) A method for treating wastewater containing formaldehyde. Water Res. 36: 633-637.

Łebkowska M., Rutkowska-Narożniak A., Pajor E., Pochanke Z. (2011) Effect of a static magnetic field on formaldehyde biodegradation in wastewater by activated sludge. Bioresource Technol. 102: 8777-8782.

Łebkowska M., Załęska-Radziwiłł M., Rutkowska-Narożniak A., Kobiela S. (2003) Toxicity assessment of wood preservatives. Environ. Int. 28: 801-802.

Marć M., Zabiegała B., Namieśnik J. (2012) Testing and sampling devices for monitoring volatile and semivolatile organic compounds in indoor air. Trends Anal. Chem. 32: 76-86.

McDermott C., Allshire A., van Pelt F.N.A.M., Heffron J.J.A. (2007) Sub-chronic toxicity of low concentrations of industrial volatile organic pollutants in vitro. Toxicol. Appl. Pharm. 219: 85-94.
Mitsui R., Omori M., Kitazawa H., Tanaka M. (2005) Formaldehyde-limited cultivation of a newly-isolated methylotrophic bacterium Methylobacterium sp MF1: enzymatic analysis related to $C 1$ metabolism. J. Biosci. Bioeng. 99(1): 18-22.

Moussavi G., Heidarizad M. (2010) Biodegradation of mixture of phenol and formaldehyde in wastewater using a singlebasin MSCR process. J. Biotechnol. 150: 240-245.

Moussavi G., Yazdanbakhsh A., Heidarizad M. (2009) The removal of formaldehyde from concentrated synthetic wastewater using $\mathrm{O}_{3} / \mathrm{MgO} / \mathrm{H}_{2} \mathrm{O}_{2}$ process integrated with the biological treatment. J. Hazard. Mater. 171: 907-913.

Munger, William J., Jacob D.J., Daube B.C., Horowitz L.W., Keene W.C., Heikes B.G. (1995) Formaldehyde, glyoxal, and methylglyoxal in air and cloudwater at a rural mountain site in central Virginia. J. Geophys. Res. 100 (D5): 9325.

Munoz M., Pliego G., Pedro Z.M., Casas J.A., Rodriguez J.J. (2014) Application of intensified Fenton oxidation to the treatment of sawmill wastewater. Chemosphere 109: 34-41.

Muto H., Sugawara T. (2001) Polychlorinated dibenzo-p-dioxins and dibenzofurans in plywood combustion gas. Chemosphere 45: 145-150.

Nemli G., Öztürk I. (2006) Influences of some factors on the formaldehyde content of particleboard. Build. Environ. 41: 770-774.

PAN Pesticide Database. Formaldehyde. http://www.pesticide info.org/

Park B.-D., Jeong H.-W. (2011) Hydrolytic stability and crystallinity of cured urea-formaldehyde resin adhesives with different formaldehyde/urea mole ratios. Int. J. Adhes. Adhes. 31: 524-529.

Priya K.R., Sandhya S., Swaminathan K. (2009) Kinetic analysis of treatment of formaldehyde containing wastewater in UAFB reactor. Chem. Eng. J. 148: 212-216.

Que Z., Furuno T., Katoh S., Noshino Y. (2007) Evaluation of three test methods in determination of formaldehyde emission from particleboard bonded with different mole ratios in the urea-formaldehyde resin. Build. Environ. 42: 1242-1249.

Rogers W., Hoppins C., Gombos Z., Summerscales J. (2014) In-mould gel-coating of polymer composites: a review. J. Clean. Produc. 70: 282-291.

Salthammer T., Fuhrmann F., Kaufhold S., Meyer B., Schwarz A. (1995) Effects of climatic parameters on formaldehyde concentrations in indoor air. Indoor Air 5(2): 120-128.

Schwingel de Oliveira I., Viana L., Verona C., Vargas Fallavena V.L., Nunes Azevedo C.M., Pires M. (2007) Alkydic resin wastewaters treatment by Fenton and photo-Fenton processes. J. Hazard. Mater. 146(3): 564-568.

Sexton K., Liu K.-S., Petreas M.X. (1986) Formaldehyde concentrations inside private residences: a mail-out approach to indoor air monitoring. J. Air Pollut. Control Assoc. 36(6): 698-704.

Silva D.A.L., Lahr F.A.R., Varanda L.D., Christoforo A.L., Ometto A.R. (2015) Environmental performance asses- 
sment of the melamine-urea-formaldehyde (MUF) resin manufacture: a case study in Brazil. J. Clean. Production. 96: 299-307.

Singh A.P., Singh T. (2014) Biotechnological applications of wood-rotting fungi: a review. Biomass Bioenerg. 62: 198206.

Solberg S., Dye C.,Walker S., Simpson D. (2001) Long-term measurements and model calculations of formaldehyde at rural European monitoring sites. Atmos. Environ. 35: 195207.

Söderberg T.A., Johansson A., Gref R. (1996) Toxic effects of some conifer resin acids and tea tree oils on human epithelial and fibroblast cells. Toxicol. 107: 99-109.

Tago H., Kimura H., Kozawa K., Fujie K. (2005) Formaldehyde concentrations in ambient air in urban and rural areas in Gunma prefecture, Japan. Water Air Soil Pollut. 163(1-4): 269-280.

TOXNET Database. Formaldehyde. https://toxnet.nlm. nih.gov/

Wang S.-Y., Yang T.-H., Lin L.-T., Lin C.-J., Tsai M.-J. (2007) Properties of low-formaldehyde-emission particleboard made from recycled wood-waste chips sprayed with PMDI/PF resin. Build. Environ. 42: 2472-2479.

Wei W., Wang S., Chatani S., Klimont Z., Cofala J., Hao J. (2008) Emission and speciation of non-methane volatile organic compounds from anthropogenic sources in China. Atmos. Environ. 42: 4976-7988.

Wiglusz R., Sitko E., Nikel G., Jarnuszkiewicz I., Igielska B. (2002) The effect of temperature on the emission of formaldehyde and volatile organic compounds (VOCs) from laminate flooring - case study. Build. Environ. 37: 41-44.

Yang H.-J., Lee S.-H., Jin Y., Choi J.-H., Han D.-U., Chae C., Lee M.-H., Han C.-H. (2005) Toxicological effects of acrylamide on rat testicular gene expression profile. Reprod. Toxicol. 19: 527-534.

Zhang W., Ma Y., Xu Y., Wang C., Chu F. (2013) Lignocellulosic ethanol residue-based lignin-phenol-formaldehyde resin adhesive. Int. J. Adhes. Adhes. 40: 11-18.

Zhu, J., Zhang, J., Shaw C.Y. (1999) Chemical composition analysis and its application in estimation of VOC emission rates from hydrocarbon solvent-based indoor materials. Chemosphere 39(14): 2535-2547.

Zuraimi M.S., Tham K.W., Sekhar S.C. (2004) A study on the identification and quantification of sources of VOCs in five air-conditioned Singapore office buildings. Build. Environ. 39: 165-177. 